\title{
FIELD TRIALS OF ADJUVANT AND SALINE INFLUENZA
}

\section{VACCINES}

\author{
BY \\ W. J. HERBERT, S. SELWYN, AND J. R. PHILP* \\ From the Department of Bacteriology, University of Edinburgh Medical School
}

Satisfactory protection against influenza can be obtained by the use of vaccines which contain prevalent strains of killed influenza virus (e.g. Hawkins, Hatch, and McDonald, 1956; Meiklejohn, 1962). The antigenic material is usually suspended either in saline or in a vehicle which has an adjuvant effect. Unfortunately the antibody response after saline vaccine is relatively transient, even when a booster dose is given some weeks after the primary injection (Hennessy and Davenport, 1961). Saline vaccines also tend to produce unpleasant local and general reactions (MRC, 1957; Meichen, Rogan, and Howell, 1962).

In contrast, enhanced and prolonged antibody responses were obtained in early tests using adjuvant vaccines (Henle and Henle, 1945; Salk, 1953). More recently these results have been confirmed, but there have been wide variations in the reported incidence of side-effects. Thus, Davenport (1961), reviewing a large series of vaccinations in the USA, found no evidence of severe reactions. But during a preliminary trial carried out in Great Britain there was a high incidence of both local and systemic reactions (MRC, 1957), while in later tests side-effects were absent (Himmelweit, 1960).

Recently a large-scale clinical trial was carried out in Great Britain with two monovalent influenza vaccines of the adjuvant type (MRC, 1964). Detailed serological studies were performed by Hobson, Lane, Beare, and Chivers (1964) on a small proportion of the volunteers receiving Asian influenza vaccine in this trial. The need was expressed, however, for a direct comparison of the âdjuvant vaccine with a conventional saline vaccine. In the present work, this direct comparison has been made during studies upon the acceptability and efficacy of a bivalent

* Present address: Department of Materia Medica and Therapeutics, University of Aberdeen. influenza vaccine of the adjuvant type which has been made commercially available in Britain for the first time.

\section{Materials AND Methods}

Two groups of volunteers took part: 88 medical students (aged between 20 and 26 years) and 66 industrial laboratory workers (aged between 21 and 59 years, average 31 years). Adjuvant and saline vaccines were allocated at random within each group, 42 students and 32 workers receiving adjuvant vaccine, and 46 students and 34 workers receiving saline vaccine. The two groups of laboratory workers proved to have very similar age distributions despite the wide scatter.

The adjuvant vaccine ("Admune") dispensed in cartridges containing $0.25 \mathrm{ml}$., was injected deep into the deltoid muscle using a cartridge syringe. Each dose contained 1,500 and 500 haemagglutinating (HA) units of Asian strains A2/Singapore/1/57 and A2/England/1/61 respectively, together with 1,000 HA units of type B virus (strain B/England/939/59). The vehicle was a water-in-oil emulsion of Drakeol 6 VR and Arlacel A (MRC, 1964). The saline vaccine was administered subcutaneously in a 1-ml. dose containing five times as much of each antigen as did a single dose of adjuvant vaccine.

Blood samples were collected before, and at one month after immunization from both groups; and again at 8 months from the laboratory workers, and at 4 months and approximately one year from the students.

Sera were treated with Vibrio cholerae filtrate, and antibody titrations were carried out by the haemagglutination-inhibition (HI) technique on Perspex plates (WHO, 1953), using 4 HA units of A2/Singapore/1/57 and B/England/939/59. Tests for ovalbumin antibody were performed by the tanned red cell technique. 
RESULTS

Figs 1 and 2 depict the trends in the levels of antibody in each group. The mean antibody titres before and after vaccination are given in Table I (opposite) with the proportion with 8-fold or higher rises in titre. As shown, the titres reached similar levels in both the adjuvant and saline groups one month after injection; but, while these levels were well maintained in later specimens from the adjuvant groups, they fell considerably in the saline groups. Another marked difference between the groups was in the numbers of volunteers showing further rises in antibody titres after the first month. Thus, although only 5 per cent. of the students receiving saline vaccine showed a 4-fold or higher rise in antibody to A2 virus between the first and fourth months, 45 per cent. of those receiving adjuvant vaccine had this further rise. The comparable values against $B$ virus were 7 and 38 per cent. in the saline and adjuvant groups respectively.

No ovalbumin antibody was detected in the sera of any of the volunteers either before or after vaccination.

None of the volunteers developed severe local or general reactions. Table II (opposite) shows the incidence of side-effects encountered. Pain and malaise accounted for most of the reactions, and the information was elicited only after specific inquiry. The local lesions were seen as moderate areas of erythema, induration, and swelling persisting for several days.

No illnesses suggestive of influenza occurred in any of the volunteers during the follow-up period, but the incidence of influenza in the general population was low during this period.

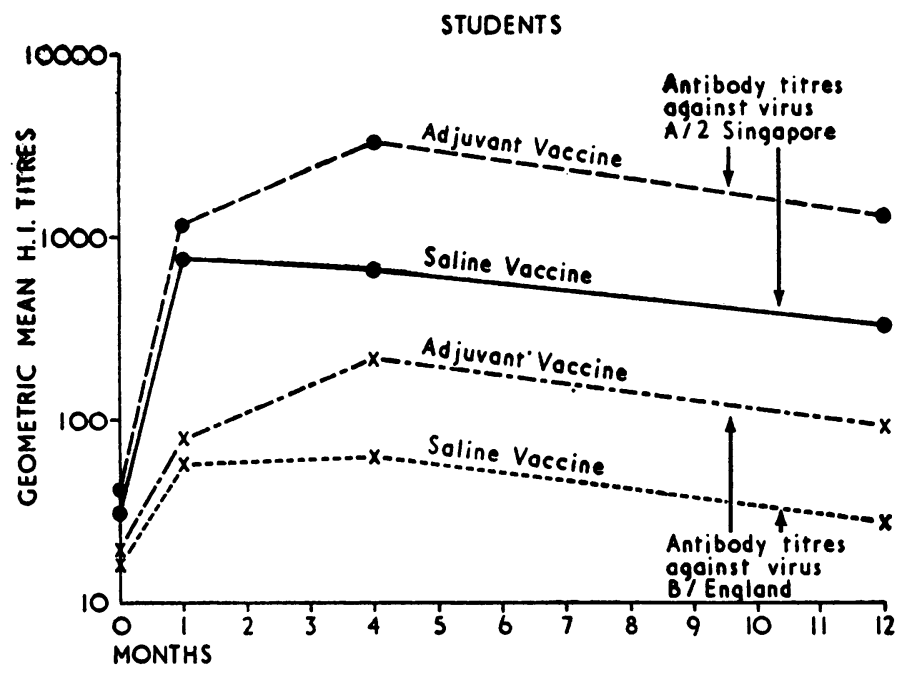

Fig. 1.-Antibody trends in students receivin adjuvant or saline vaccine.

INDUSTRIAL LABORATORY STAFF

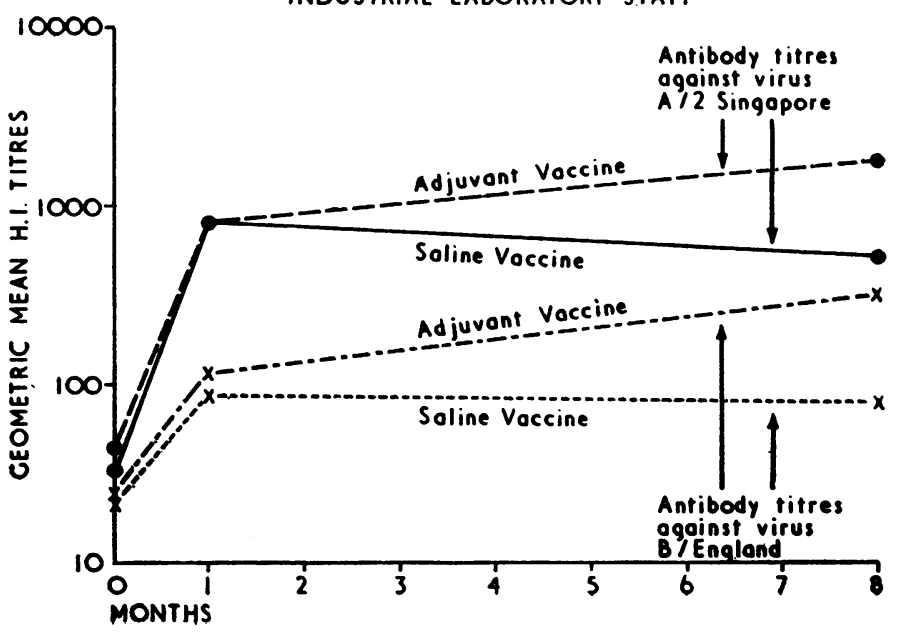

Fio. 2.-Antibody trends in laboratory workers receiving adjuvant or saline vaccine. 
TABLE I

GEOMETRIC MEAN ANTIBODY TITRES* BEFORE AND AFTER ADMINISTRATION OF SALINE AND ADJUVANT INFLUENZA VACCINES

\begin{tabular}{|c|c|c|c|c|c|c|}
\hline $\begin{array}{c}\text { Vaccination } \\
\text { Group }\end{array}$ & Antigen & Before & 1 month after & 4 months after & 8 months after & 12 months after $\dagger$ \\
\hline \multirow{2}{*}{ Students } & $\begin{array}{l}\text { Saline A2 } \\
\text { Adjuvant A2 }\end{array}$ & $\begin{array}{l}31 \\
41\end{array}$ & $\begin{array}{r}747(83) \\
1,166(91)\end{array}$ & $\begin{array}{r}639(77) \\
3,080(95)\end{array}$ & - & $\begin{array}{r}322(57) \\
1,324(82)\end{array}$ \\
\hline & $\begin{array}{l}\text { Saline B } \\
\text { Adjuvant B }\end{array}$ & $\begin{array}{l}16 \\
18\end{array}$ & $\begin{array}{l}58(22) \\
78(38)\end{array}$ & $\begin{array}{r}64(30) \\
210(59)\end{array}$ & - & $\begin{array}{l}28(28) \\
94(51)\end{array}$ \\
\hline \multirow{2}{*}{ Workers } & $\begin{array}{l}\text { Saline A2 } \\
\text { Adjuvant A2 }\end{array}$ & $\begin{array}{l}34 \\
38\end{array}$ & $\begin{array}{l}785(83) \\
784(84)\end{array}$ & - & $\begin{array}{r}507(58) \\
1,743(96)\end{array}$ & - \\
\hline & $\begin{array}{l}\text { Saline B } \\
\text { Adjuvant B }\end{array}$ & $\begin{array}{l}22 \\
25\end{array}$ & $\begin{array}{r}87(35) \\
116(41)\end{array}$ & 二 & $\begin{array}{r}76(24) \\
312(73)\end{array}$ & - \\
\hline
\end{tabular}

* Figures in brackets denote the percentage of subjects with 8-fold or higher rises in titres as compared with pre-immunization values.

t Final serum specimens obtained from 43 students and 26 workers receiving saline vaccine, and from forty students and 26 workers receiving adjuvant vaccine.

TABLE II

REACTIONS TO SALINE AND ADJUVANT INFLUENZA VACCINES

\begin{tabular}{|c|c|c|c|c|c|c|c|c|}
\hline \multirow{3}{*}{$\begin{array}{l}\text { Vaccination } \\
\text { Group }\end{array}$} & \multirow{3}{*}{ Vehicle } & \multirow{3}{*}{ No. } & \multirow{3}{*}{$\begin{array}{c}\text { General } \\
\text { Reactions }\end{array}$} & \multicolumn{4}{|c|}{ Local Reactions } & \multirow{3}{*}{$\begin{array}{c}\text { Total } \\
\text { with } \\
\text { Reactions }\end{array}$} \\
\hline & & & & \multicolumn{3}{|c|}{ Pain (duration in days) } & \multirow{2}{*}{$\begin{array}{c}\text { Minor } \\
\text { Lesions }\end{array}$} & \\
\hline & & & & 1 & $2-3$ & $4-5$ & & \\
\hline Students & $\begin{array}{l}\text { Saline } \\
\text { Adjuvant }\end{array}$ & $\begin{array}{l}46 \\
42\end{array}$ & $\begin{array}{l}4 \\
7\end{array}$ & $\begin{array}{r}24 \\
9\end{array}$ & $\begin{array}{r}7 \\
18\end{array}$ & $\begin{array}{l}0 \\
4\end{array}$ & $\begin{array}{l}5 \\
0\end{array}$ & $\begin{array}{l}35 \\
33\end{array}$ \\
\hline Workers & $\begin{array}{l}\text { Saline } \\
\text { Adjuvant }\end{array}$ & $\begin{array}{l}34 \\
32\end{array}$ & $\begin{array}{l}3 \\
0\end{array}$ & $\begin{array}{l}6 \\
3\end{array}$ & $\begin{array}{r}9 \\
12\end{array}$ & $\begin{array}{l}2 \\
1\end{array}$ & $\begin{array}{r}17 \\
1\end{array}$ & $\begin{array}{l}20 \\
17\end{array}$ \\
\hline
\end{tabular}

Discussion

The most striking finding in this study is the excellent and prolonged antibody response following the administration of a single dose of a relatively small amount of antigenic material contained in a commercially available oil-adjuvant vaccine. In comparison, a saline vaccine, although containing five times as much of each antigen suspended in four times the volume, gave titres which were at one month slightly inferior to those following adjuvant vaccine, and which thereafter showed a steady decline. In general the titres against $\mathrm{A} 2$ virus in volunteers receiving adjuvant vaccine are higher than those reported by Hobson and others (1964). These investigators, however, used $8 \mathrm{HA}$ units of a less avid strain of virus in their haemagglutination-inhibition tests.

The relatively poor response obtained in all cases to type B virus was partly due both to the smaller dose used in the vaccine and to the lower initial titres present, but the inherently poor antigenicity of this virus was probably an important factor. The superiority of the adjuvant vaccine was, however, as evident with the type $B$ as with the type $A 2$ virus.

The incidence of minor side-effects was high with both vaccines, and, although slight local pain tended to persist longer in the volunteers receiving the adjuvant vaccine than in those receiving the saline vaccine, local lesions were confined almost entirely to the saline group-probably because of the subcutaneous route of injection used in this group. Specific serological tests revealed no evidence of sensitization to egg protein; and despite the frequency of slight reactions almost all the volunteers agreed that both vaccines were quite acceptable. The safety of the adjuvant itself is now well-established. Thus, Cutler, Lesesne, and Vaughn (1962), using the same water-in-oil emulsion in a poliomyelitis vaccine trial, reported that only $1 \cdot 1$ per cent. of recipients experienced any side-effects, and these consisted almost entirely of slight local pain and tenderness.

The excellent antibody response elicited by a small, single injection of the adjuvant influenza vaccine makes it particularly suitable for use in children, who probably constitute an important temporary reservoir of influenza virus (Hennessy, Davenport, Horton, Napier, and Francis, 1964). Such a vaccine should also be of great value in the face of an epidemic, when the latest virus strain could be incorporated with great economy of material. Nevertheless, the reactions that are encountered with the influenza virus vaccines currently available could militate against a successful vaccination programme, both in children and in the large and vulnerable working population. Consequently, the recent work 
on a non-toxic, fully antigenic saline vaccine which contains purified viral haemagglutinins is of great practical interest (Davenport, Hennessy, Brandon, Webster, Barrett, and Lease, 1964). Relatively small amounts of such material incorporated in an adjuvant similar to that used in the present work may prove to be very close indeed to the ideal influenza vaccine.

\section{SUMMARY}

A commercially available, single-dose influenza vaccine ("Admune") containing a light mineral oil adjuvant was tested for efficacy and acceptability. In a group of 154 volunteers (medical students and industrial laboratory workers), this vaccine was compared with a conventional saline preparation-each dose of which contained five times as much influenza $A 2$ and $B$ antigens as did the adjuvant vaccine.

After one month, equally satisfactory serum antibody titres were obtained with both vaccines. During the next 3 to 7 months, a continuing rise in titres occurred in most of the recipients of adjuvant vaccine, and after one year the titres were well maintained. In contrast, a considerable fall in titres after one month was usual in the saline vaccine groups. Ovalbumin antibodies were not detected in any of the volunteers.

No severe reactions occurred, although slight local pain was common for a few days after adjuvarit vaccine, as was local induration in those receiving the saline vaccine.
The vaccines used were provided by $\operatorname{Dr} D$. Hobson, Evans Medical Ltd, Liverpool. We wish to thank Dr E. V. Kuenssberg and members of this Department for their assistance in the trial. One of us (W.J.H.) was supported by a grant from the Animal Health Trust.

\section{REFERENCES}

Cutler, J. C., Lesesne, L., and Vaughn, I. (1962). J. Allergy, 33, 193.

Davenport, F. M. (1961). "International Conference on Asian Influenza, Bethesda, Maryland, 1960", Amer. Rev. resp. Dis., 83, Suppl. (No. 2, part 2), p. 146.

, Hennessy, A. V., Brandon, F. M., Webster, R. G., Barrett, C. D., Jr., and Lease, G. O. (1964). J. Lab. clin. Med., 63, 5.

Hawkins, G. F. C., Hatch, L. A., and McDonald, J. C. (1956). Brit. med. J., 2, 1200.

Henle, W., and Henle, G. (1945). Proc. Soc. exp. Biol. (N.Y.), 59, 179.

Hennessy, A. V., and Davenport, F. M. (1961). Publ. Hlth Rep. (Wash.), 76, 411.

- , Horton, R. J. M., Napier, J. A., and Francis, T., Jr. (1964). Milit. Med., 129, 38.

Himmelweit, F. (1960). Brit. med.J., 2, 1690.

Hobson, D., Lane, C. A., Beare, A. S., and Chivers, C. P. (1964). Ibid., 2, 271.

MRC (1957). "Report by Committee on Clinical Trials of Influenza Vaccine", Ibid., $2,1$.

MRC (1964). "Report by Committee on Influenza and Other Respiratory Virus Vaccines", Ibid., 2, 267.

Meichen, F. W., Rogan, E., and Howell, R. W. (1962). Brit.J. industr. Med., 19, 203.

Meiklejohn, G. (1962). J. Amer. med. Ass., 179, 594.

Salk, J. E. (1953). Ihid., 151, 1169.

World Health Organization Expert Committee on Influenza (1953). Wld Hlth Org. techn. Rep. Ser. No. 64. 